\title{
Keyboarding Assignments
}

\section{A Photocopiable Pack}

\author{
Maureen Cole
}

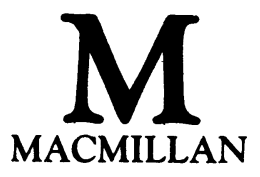


(C) Maureen Cole 1991

Softcover reprint of the hardcover 1st edition 1991

All rights reserved. No reproduction, copy or transmission of this publication may be made without written permission.

No paragraph of this publication may be reproduced, copied or transmitted save with written permission or in accordance with the provisions of the Copyright, Designs and Patents Act 1988 , or under the terms of any licence permitting limited copying issued by the Copyright Licensing Agency,

33-4 Alfred Place, London WC1E 7DP.

The purchaser is licensed to copy, for educational purposes only and within the purchasing institution, all material on pages 3-37, 41-99 and 103-147.

Any person who does any unauthorised act in relation to this publication may be liable to criminal prosecution and civil claims for damages.

First edition 1991

Published by

MACMILLAN EDUCATION LTD

Houndmills, Basingstoke, Hampshire RG21 2XS

and London

Companies and representatives

throughout the world

British Library Cataloguing in Publication Data

Cole, Maureen

Keyboarding assignments.

1. Word processing. Keyboarding

I. Title

652.5

ISBN 978-1-349-11394-1

ISBN 978-1-349-11392-7 (eBook)

DOI 10.1007/978-1-349-11392-7 


\section{Contents}

Acknowledgements

Introduction

Marking Schemes

vii

Examples of Theory

Section I

1 Hotel Griffon

2 Buying a House

3 Saunders \& Briggs

4 A Broken Shoe Heel

5 Going to Appeal

6 Greek Holiday

7 Working for a Travel Agent

8 The Wedding

9 Membership of a Pony Club

10 Craven Young Farmers' Club

11 Answering a Job Advertisement

12 A School Leaver's First Job 
13 A Visit to the Vet

14 How I Regret Going to The Yew Tree

Section III

15 Fragrance

16 Buying Make-up

17 Going to the Sales

18 Organising an Outing

19 Organisation of a Disco

20 Buying from a Mail Order Catalogue

21 Oh You Beautiful Baby 
The following are thanked for their co-operation in producing handwritten material: Linda Albin, Doreen Alig, Peggy Cantello, Tom Hardy, Sue James, Roda Morrison, Sue Roberts, Steve Rutt, Frances Somers Cocks, Malcolm Stewart, Leonie Stone, Beverley Tarquini, Nicola Tigwell, Pauline Underwood and Cecily Wilson.

The extract from the catalogue on page 136 is reproduced with the permission of Argos Distributors Limited. 


\section{Introduction}

This book is designed to stimulate research, and the use of theory where appropriate, as well as to develop practical skills at the keyboard(s).

Keyboarding Assignments can be used with either a typewriter or a WP. The 'Assignment' format was devised to introduce a new approach to working. This approach suggests real-life situations to the students. Work needs to be orientated towards an integrated approach. Instructions have a personal emphasis or are written to provide a real-life situation.

Certain elements in this theme approach are applicable to the style of some examination papers. Certain skills needed for the new examinations are sometimes required to complete course work. I have tried to produce assignments which cover the demands of all the main examination boards. There is great emphasis on composition, as this is a relatively new skill required in both course work and examination papers.

Pupils enjoy participating in a situation, rather than being just set tasks to develop skills. Many skill requirements are needed to complete the various tasks. 'Skills needed' at the beginning of each assignment theme is a quick reference guide.

The themes have been built into Sections requiring definite skills. More advanced skills are required in Section III. By working in this way, the student learns to use his/her ability both in practising themes and as an introduction to examination work.

The assignments are graduated in difficulty but inevitably some have harder, although basically easy, elements. The contents have been arranged in three sections: I (easy), II (more difficult) and III (most difficult). Section III is particularly useful to develop theory skills, and to increase speed of working. Students should by this point have become used to working in a personal manner, and will hopefully delight in their participation in this section. There are elements which should test some of the more able in Section III.

All names and addresses are fictitious and do not refer to any specific individual living or dead.

Punctuation styles have been mixed deliberately. The student would be expected to be consistent in his/her use of chosen style. 


\section{Marking Schemes}

It is suggested that marking schemes are used as a guide. Reference should be made to the individual examination board for clarification of any differences, and the enclosed schemes may be adapted where necessary.

Particular reference should be made to the positive marking schemes of the boards.

$1 / 2$ Accuracy

3 Comprehension

$4 / 5$ Display and application of theoretical knowledge

6 Corrections - printer, abbreviations, spellings

7 Composition skills

A brief marking scheme is included with each Assignment. 


\section{Examples of Theory}

Advertisement

Ref. to advert

Agenda

Alpha. order

Bus. letter

Enquiry

Form letter

Reply

Tear-off slip

Chart

Chronological order

Correction passage

$\mathrm{CV}$

Form

Booking

Order

From notes

Invitation

Invoice

Itinerary

Leader dots

Leaflet

List

Manuscript

Memo

Menu

Minutes

Notice

Numerals

Postcard

Programme

Tabulation

Tel. messages

Vertical display

Voucher

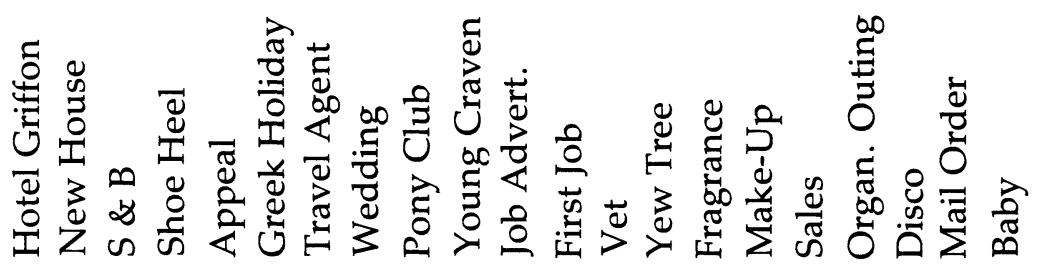

